Nigerian Journal of Physiological Sciences 24 (1): 7 - 12 @Physiological Society of Nigeria, 2009

Available online/abstracted at http://www.bioline.org.br/np; www.ajol.info/journals.njps; www.cas.org

\title{
EFFECT OF NICOTINE ADMINISTRATION ON WEIGHT AND HISTOLOGY OF SOME VITAL VISCERAL ORGANS IN FEMALE ALBINO RATS
}

\author{
B. O. IRANLOYE AND A. F. BOLARINWA ${ }^{1}$
}

\begin{abstract}
Department of Physiology, School of Basic Medical Sciences, College of Medicine, University of Lagos, Nigeria; ${ }^{1}$ Department of Physiology, Faculty of Basic Medical Sciences, College of Medicine University of Ibadan, Ibadan, Nigeria E-mail: bolasunkanmi45@yahoo.com Tel: +234-1-7202031, +234-08037127147
\end{abstract}

\begin{abstract}
Summary: It has been emphasized that cigarette smoking is not always synonymous with nicotine administration but the toxic effect of cigarette has often been associated with the nicotine content in cigarette. Epidemiologic studies have clearly indicated that cigarette smoking have many deleterious effects on visceral tissues in women. However it is not certain whether this effect is produced entirely by nicotine as cigarettes contain other toxic substances. Using an animal model the direct effect of nicotine administration on viscera tissues in female albino rats was investigated. Twenty-four female rats with regular oestrous cycle in the same phase of the cycle were divided into two equal groups with each group receiving $0.5 \mathrm{mg} / \mathrm{kg}$ nicotine and $0.9 \%$ normal saline S.C. daily respectively. Six rats from each group were killed by cervical dissociation after 30 and 60 days treatment. The ovary, uterus, brain, kidney, heart, adrenal, pituitary and the liver were removed weighed and histological study carried out. Weights of the ovary, kidney, pituitary and uterus were significantly reduced $(\mathrm{P}<0.05)$ following nicotine treatment while weights of the heart and liver increased with 60days treatment with the appearance of cartilaginous cells in the heart and deposition of adipose around the portal vein in the liver. Necrosis, congestion, fibrosis, follicular and endometrial degeneration were observed in the brain, pituitary, kidney, ovary and uterus respectively. No significant difference between the weekly growth rates in nicotine treated $(5.13 \pm .29)$ and control $(5.25 \pm 0.18)$ animals. Nicotine has deleterious effects on some vital visceral organs with observations similar to those reported in women smokers.
\end{abstract}

Keywords: Nicotine administration, cigarette smoking, visceral organs

\section{Introduction}

Nicotine is the principal alkaloid contained in tobacco and it is believed to be the primary reason for cigarette smoking in many people particularly as they derive satisfaction and pleasant sensation from inhaling nicotine (Benowitz et al, 1982). It is widely consumed through cigarette smoking and tobacco chewing in $30-40 \%$ of the world's population (Abel, 1983). In Nigeria, nicotine is an important constituent of cow urine concoction (CUC) a local panacea for the treatment of convulsion among the Yorubas (Familusi and Sinnette, 1977).

Available evidence showed that nicotine affects many biological activities. For instance, it causes bronchitis and interferes with alveoli formation causing development of emphysema-like lesion and cancer of the lungs (Maritnez, et al 1992). It also decreases exercise tolerance and causes coronary thrombosis (Benowitz et al, 1984; Sidney et al, 1993). Cigarette and tobacco have been shown extensively to affect offspring of mothers exposed to smoking. For example, intrauterine growth retardation has been observed in babies of smokers (Seller and Brait, 1995), so also are low birth weight
(Bardy et al, 1993), increase incidence of respiratory tract infection (Fergusson et al, 1981), reduced forced expiratory flow (Hanrahan et al, 1992), asthma (Weitzman et al, 1990), prenatal and neonatal death or mortality (Walsh, 1994) and reduction in uterine blood flow in both rats and humans (Birnbaun et al, 1994, Economides and Braithwaite, 1994). Men who smoke cigarette have been shown to have immature sperm, low sperm count, sperm with multiple heads (Weisberg, 1985) and decreased sperm motility and penetrability through cervical.

Cigarette smoking is known to have deleterious effects on visceral tissues in women as epidemiologic studies have clearly indicated that women who smoke suffer a lowered fertility (Rosevear et al 1992; Hughes et al 1996). Kaffman et al, (1980) and Weisberg, (1985) also reported early menopause among smokers. These toxic effects of cigarette smoking are often associated with the nicotine content of cigarettes. However, it is now well known that nicotine is not the only toxic substance in cigarette. Cigarette also contains other toxic, carcinogenic, mutagenic, growth retardative and 
B. O. Iranloye and A. F. Bolarinwa

immunosuppressive compounds such as polycyclic aromatic hydrocarbons, cyanide, carbon-monoxide, lead, cadmium nitric oxide and nitric dioxide (Halliwell, 1993a, b). Also the American tobacco industry under pressure from the American congress, released a top-secret list of other 599 chemicals it adds to cigarette which among hundreds of others include ammonia and insecticides (Brodie, 1994).

It has also been emphasized that cigarette smoking is not always synonymous with nicotine administration (Oyebola and Adetuyibi, 1977, Alada 2001). The aim of the present study is therefore to test whether administration of nicotine alone produces the same effects on viscera of rats as cigarette smoking produces in women?

\section{Materials and Methods \\ Animals}

Twenty-four female albino rats of the wistar strain with established four days normal oestrous cycle were used in the study. The animals were housed as much as possible under conditions of controlled lightening (14hours of light and 10hours of darkness) at room temperature. Rats' pellets and water were provided ad libithum and the control animals were treated with vehicle and allotted only the amount of food consumed by drug-treated animals. Animals at the same phase of the cycle were selected and used for the experiment. The animals were randomly divided into two equal groups.

Group 1 (Nicotine-treated): Twelve rats received $0.5 \mathrm{mg} / \mathrm{kg}$ nicotine s.c. daily. Six of these rats were killed by cervical dislocation after 30 and the remaining six rats were also killed after 60 days of nicotine treatments. The ovary, uterus, pituitary, heart, liver, kidney, brain and the adrenal were removed, weighed and fixed immediately in $10 \%$ formaldehyde for histological studies.

Group II (control): Twelve rats received $0.9 \%$ Normal saline S.C daily. They were subsequently killed on days 30 and 60 of treatment as described for the nicotine treated group. Body weight of each animal was taken daily and recorded for 4 weeks the growth rate per week was then calculated using the formula below: Growth rate per week $=$ Weight by week 4 -Weight by week $1 / 4$. All the animals were sacrificed at the end of the experimental period without any discomfort and all survived to the end of the experiment.

\section{Preparation of tissues for microscope examination}

The tissues removed were fixed for 7 days in $10 \%$ formaldehyde after which dehydration was carried out in ascending grade of alcohol. The tissues were then cleared of xylene overnight (16 hours) to remove the alcohol. Infiltration/impregnation was done in three changes of molten soft paraffin wax at $\leq 68^{\circ} \mathrm{c}$ for 1 hour each. Embedding and casting in paraffin wax with wooden block was done and sectioning carried out using a microtome (Leica, Germany). The sectioned tissues (heart, uterus, ovary, pituitary, liver, kidney, brain and adrenal) were mounted on slides using a thin film of egg albumen smeared on each side. Dewaxing was done using hot plate and then clearing in two changes of xylene. Xylene was removed with absolute alcohol and finally before staining, hydration was done. Haematoxylin and eosin staining was used and the slides mounted in Canada balsam. The slides were then evaluated for pathological changes under light microscope.

\section{Statistical analysis}

The mean, standard deviation (S.D) and standard error of mean (S.E.M) of all values were calculated. The results are presented as S.E.M of appropriate number of experiment (n). Observed changes in body and organ weight were analysed using the student's ttest for values between two groups (Snedecor and Cochran, 1980).

\section{Results}

The growth rate in the control and treated animals are shown in Table I. The weight of the animal treated with nicotine increased gradually from 130.00 $\pm 3.23 \mathrm{~g}$ in the first week to $150.50 \pm 2.69 \mathrm{~g}$ at the end of the fourth week. The weight of the control animal treated with normal saline increases from $135.00 \pm$ $1.38 \mathrm{~g}$ to $156.3 \pm 1.12 \mathrm{~g}$ in four weeks. No significant difference was observed between the growth rate in the control in the control and nicotine treated rats.

Table 1: Growth rate in Normal Saline and Nicotine Treated Rats.

\begin{tabular}{|c|c|c|c|}
\hline Group & $\begin{array}{c}\text { Body } \\
\text { weight }(\mathrm{g})\end{array}$ & \multicolumn{2}{|c|}{$\begin{array}{c}\text { Growth rate per } \\
\text { week (g/week) }\end{array}$} \\
\cline { 2 - 4 } & Week 1 & Week 4 & \\
\hline Group I & $130.00 \pm$ & $150.50 \pm$ & $5.13 \pm$ \\
(nicotine- & 3.23 & 2.70 & $.29 \mathrm{NS}$ \\
treated). & & & \\
\hline Group II & $135.30 \pm$ & $156.30 \pm$ & $5.25 \pm$ \\
(Control). & 1.38 & 0.12 & 0.18 \\
\hline
\end{tabular}

NS means not significant $(\mathrm{P}>0.05)$

The effect of $0.5 \mathrm{mg} / \mathrm{kg}$ nicotine on the weight of the tissues is shown in Table 2. There was a progressive reduction in the weight of the ovary following administration of nicotine between 30 and 60 days. The ovarian weight reduced from $0.12 \pm$ $0.01 \mathrm{~g}$ to $0.05 \pm 0.01$ in 30 days and $0.12 \pm 0.14$ to $0.03 \pm 0.002$ in 60 days. Both decreases were statistically significant $(\mathrm{p}<0.05)$. The section 
Nicotine and some vital visceral organs

through the ovary of nicotine-treated rats showed high follicular degeneration and evidence of fibrosis (indicated by the changes in the shape of the follicle as seen in figure 2).

Nicotine administration for 30 days did not produce any significant effect on the weight of the uterus, the pituitary, the kidney, and the liver. However, after 60 days treatment with nicotine, the weight of the uterus reduced significantly from 0.56 \pm 0.02 to $0.48 \pm 0.13(\mathrm{p}<0.05)$, while the weight of the Pituitary is reduced from $0.07 \pm 0.002$ to $0.01 \pm$ 0.001 . 60 days nicotine treatment caused a significant increase in the weight of the liver (from $6.10 \pm 0.23$ to $7.39 \pm 0.05) .0 .5 \mathrm{mg} / \mathrm{kg}$ nicotine treatment for 30 days caused the weight of the heart to reduce significantly from $0.61 \pm 0.01$ to $0.56 \pm 0.01$ $(\mathrm{p}<0.05)$. However, when nicotine treatment was maintained for 60 days, the weight of the heart in the rats increased significantly from $0.62 \pm 0.01$ to $0.67 \pm$ $0.01(\mathrm{p}<0.05)$.

Histological section through the pituitary in nicotine treated rats showed progressive necrosis of the cells in the anterior pituitary (from 30 to 60 days nicotine treatment) figure 3 ). The histological slide from the heart tissue in animals treated for 30 days with nicotine $(0.5 \mathrm{mg} / \mathrm{kg})$ show distortion of the normal striation, loss of nuclei in some muscles and also presence of dead tissues and embolism (figure 4a). Section through the heart after 60 days of nicotine treatment showed the deposition of calcified plaque and dead tissues (figure $4 \mathrm{~b}$ ). Histology of liver in rat treated with 60 days $0.5 \mathrm{mg} / \mathrm{kg}$ nicotine showed the appearance of adipose tissues close to the portal vein (figure 5). The adipose deposition along the portal vein increases with 60 days nicotine treatment.

No significant change was noticed in the weights of adrenal and the brain. Also little necrosis, endometrial degeneration and congestion were observed in the brain, the uterus and the kidney respectively.

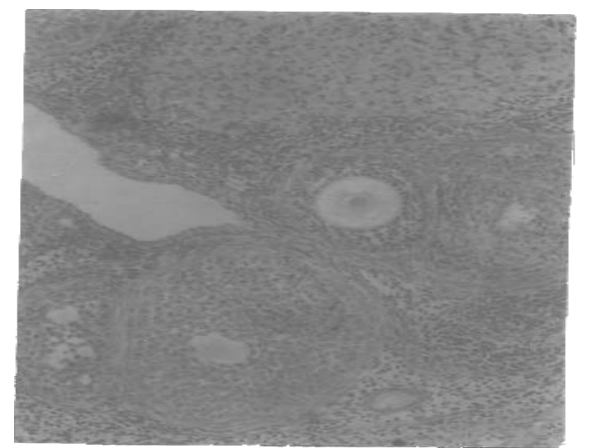

A

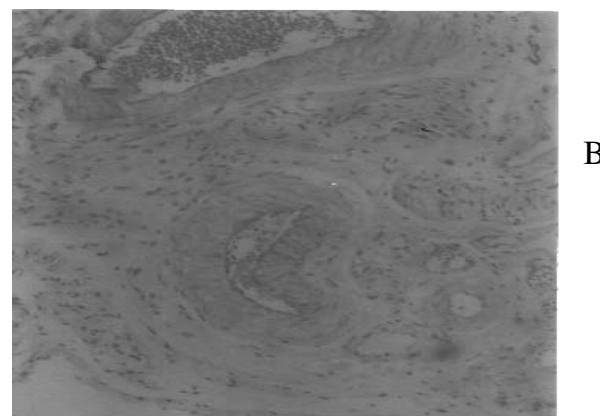

Figure 1:Section through the ovary in (A) 30 days and $(B) 60$ days $0.5 \mathrm{mg} / \mathrm{kg}$ nicotine treated rats Sections show lot of primary $(P)$, secondary $(s)$ and atretic (A) with no matured follicle Fibrosis is indicated by changes in the shape of the follicles in $(b)$.

Table 2: Effect of 0.9\% Normal Saline and $0.5 \mathrm{mg} / \mathrm{kg}$ Nicotine on the weight of the tissues.

\begin{tabular}{|c|c|c|c|c|c|c|c|c|c|}
\hline \multirow[t]{2}{*}{ Groups } & & \multicolumn{8}{|c|}{ Tissues Weights } \\
\hline & & $\begin{array}{l}\text { Heart } \\
(g)\end{array}$ & Uterus $(g)$ & $\begin{array}{c}\text { Ovary } \\
(g)\end{array}$ & $\begin{array}{l}\text { Pituitary } \\
(g)\end{array}$ & $\begin{array}{l}\text { Liver } \\
(g)\end{array}$ & $\begin{array}{c}\text { Kidney } \\
(g)\end{array}$ & $\begin{array}{c}\text { Brain } \\
(g)\end{array}$ & $\begin{array}{c}\text { Adrenal } \\
(\mathrm{g})\end{array}$ \\
\hline $\begin{array}{c}\text { Group I } \\
(0.9 \% \\
\text { Normal }\end{array}$ & $\begin{array}{c}30 \text { Days } \\
\text { Treatment }\end{array}$ & $\begin{array}{c}0.614 \pm \\
0.012\end{array}$ & $\begin{array}{c}0.568 \pm \\
0.078\end{array}$ & $\begin{array}{c}0.117 \pm \\
0.014\end{array}$ & $\begin{array}{c}0.070 \pm \\
0.003\end{array}$ & $\begin{array}{c}6.098 \pm \\
0.231\end{array}$ & $\begin{array}{c}0.804 \pm \\
0.538\end{array}$ & $\begin{array}{l}2.485 \\
\pm 0.02\end{array}$ & $\begin{array}{c}0.025 \pm \\
0.002\end{array}$ \\
\hline Saline) & $\begin{array}{l}60 \text { days } \\
\text { Treatment }\end{array}$ & $\begin{array}{c}0.618 \pm \\
0.010\end{array}$ & $\begin{array}{c}0.563 \pm \\
0.018\end{array}$ & $\begin{array}{c}0.117 \pm \\
0.014\end{array}$ & $\begin{array}{c}0.069 \pm \\
0.002\end{array}$ & $\begin{array}{c}6.100 \pm \\
0.229\end{array}$ & $\begin{array}{c}0.801 \pm \\
0.050\end{array}$ & $\begin{array}{l}2.481 \\
\pm 0.02\end{array}$ & $\begin{array}{c}0.028 \pm \\
0.001\end{array}$ \\
\hline $\begin{array}{c}\text { Group II } \\
(0.5 \mathrm{mg} / \\
\mathrm{kg}\end{array}$ & $\begin{array}{c}30 \text { Days } \\
\text { Treatment }\end{array}$ & $\begin{array}{c}0.563 \pm \\
0.005\end{array}$ & $\begin{array}{c}0.545 \pm \\
0.026\end{array}$ & $\begin{array}{c}0.053 \pm \\
0.005\end{array}$ & $\begin{array}{c}0.042 \pm \\
0.001\end{array}$ & $\begin{array}{c}6.959 \pm \\
0.080\end{array}$ & $\begin{array}{c}0.683 \pm \\
0.014\end{array}$ & $\begin{array}{l}2.367 \\
\pm 0.18\end{array}$ & $\begin{array}{c}0.046 \pm \\
0.006\end{array}$ \\
\hline Nicotine) & $\begin{array}{c}60 \text { Days } \\
\text { Treatment }\end{array}$ & $\begin{array}{c}0.668 \pm \\
0.008\end{array}$ & $\begin{array}{c}0.476 \pm \\
0.013\end{array}$ & $\begin{array}{c}0.031 \pm \\
0.002\end{array}$ & $\begin{array}{c}0.011 \pm \\
0.001\end{array}$ & $\begin{array}{l}7.39 \pm \\
0.050\end{array}$ & $\begin{array}{c}0.631 \pm \\
0.009\end{array}$ & $\begin{array}{l}2.061 \\
\pm 0.03\end{array}$ & $\begin{array}{c}0.048 \pm \\
0.003\end{array}$ \\
\hline
\end{tabular}


B. O. Iranloye and A. F. Bolarinwa
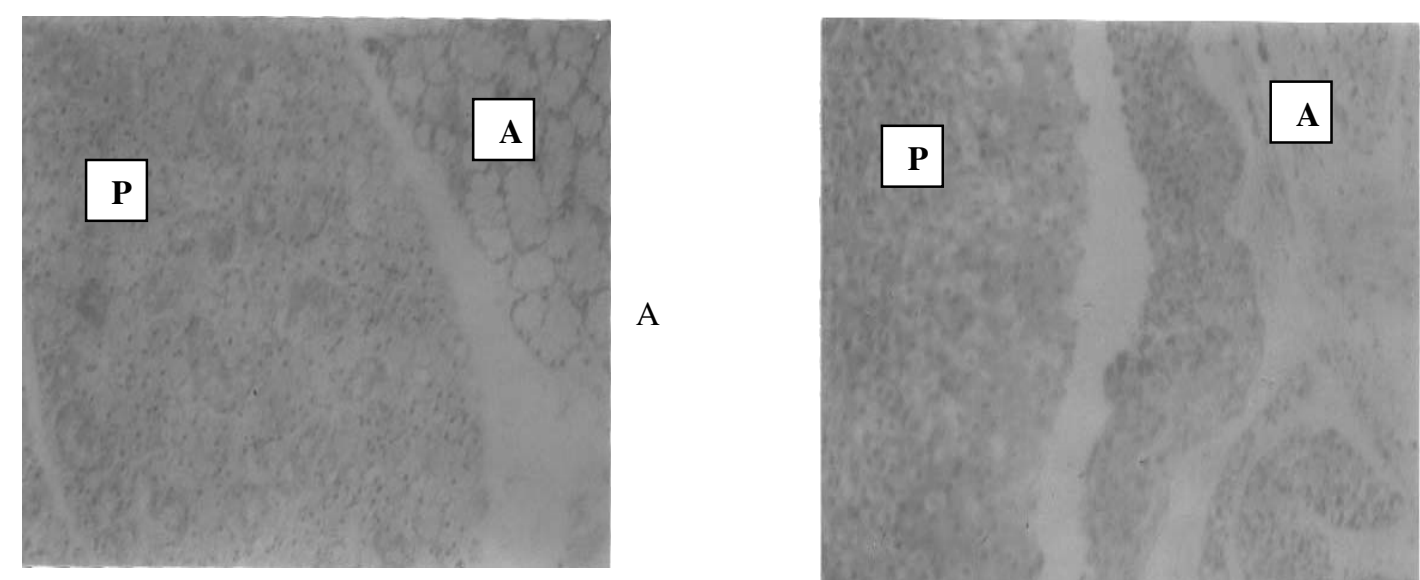

Figure 2: Section through the pituitary of $0.5 \mathrm{mg} / \mathrm{kg}$ nicotine treated rats. The posterior pituitary $(P)$ and the anterior pituitary (A) shows progressive necrosis of the cells in (A) 30 days and (B) 60 days nicotine treated rats respectively.

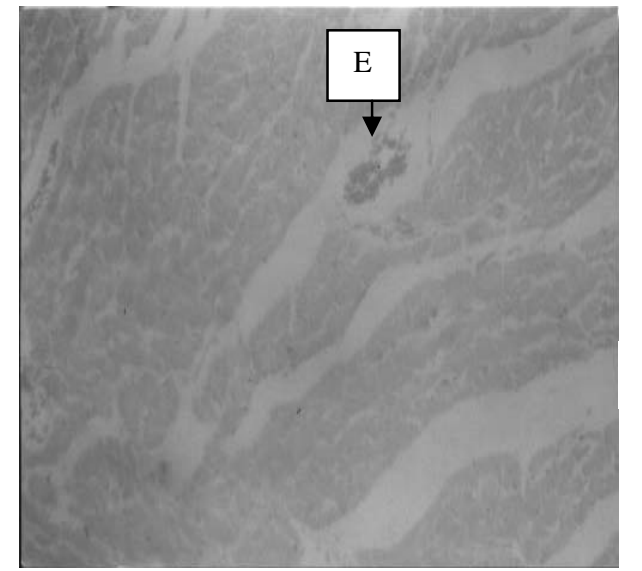

A

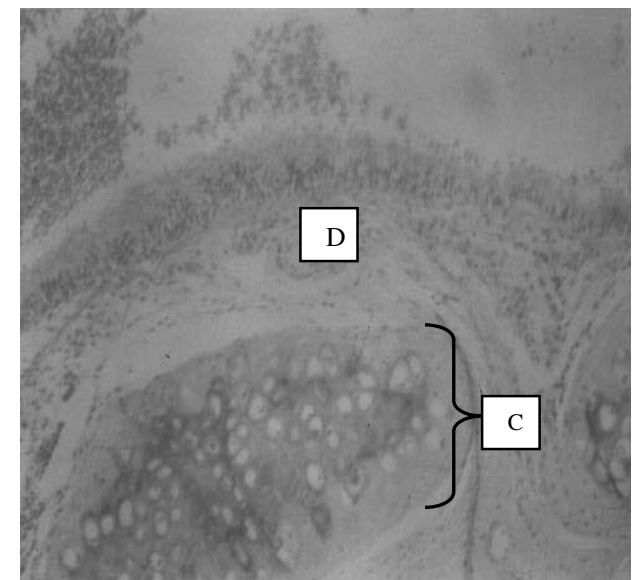

B

Figure 3: Section through the heart of a rat treated with $0.5 \mathrm{mg} / \mathrm{kg}$ nicotine. (A): shows embolism (E) in 30days nicotine treated rats. $(B)$ : shows the deposition of cartilaginous cells $(C)$ and lots of dead tissues $(D)$ in 60days nicotine rat treated.
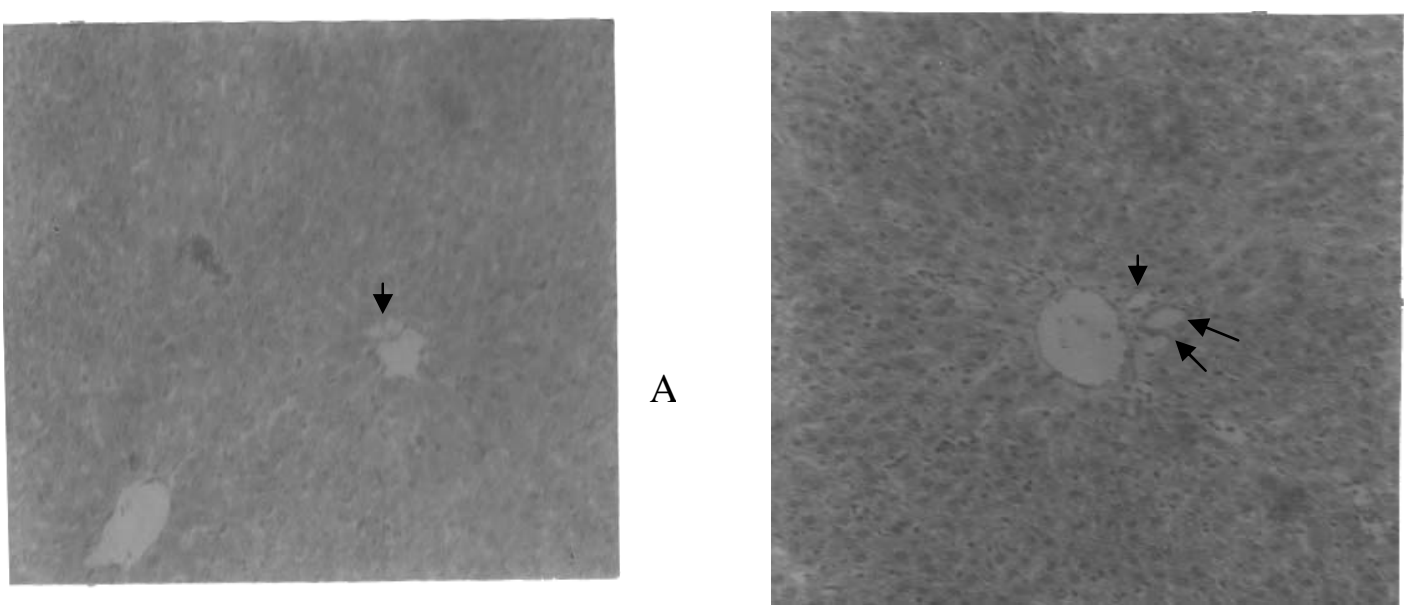

Figure 4: Section through the liver of rat treated with $0.5 \mathrm{mg} / \mathrm{kg}$ nicotine for 30 days $(A)$ and 60 days $(B)$. The figure shows some adipose deposition around the portal vein indicated by the arrows. 
Nicotine and some vital visceral organs

\section{Discussion}

This study showed that chronic nicotine treatment with pair feeding has no significant effect on body weights and growth rate in non- pregnant female albino rats of the Wistar strain. This is consistent with the work of Perkins et al, 1994 reported no difference in total caloric intake or micronutrient or taste selection in smokers and non-smokers. Also the work of Winders and Grunberg (1993) showed that nicotine administration produce no comparable cumulative effect on growth rate even though he reported changes in food consumed and body weight. Liver:

The major organ for nicotine metabolism is the liver, although metabolism occurs to some extent in the kidney and lungs. The observed hepatomegaly and fat deposition obtained in this study following progressive increase in duration of treatment leads to suspicion of some degree of toxicity, since this did not occur in the control rats. Enlargement of the liver occurs when lipid accumulates as a result of diseases of the parenchyma cells of the liver (Martin, 1983), thus suggesting the possibility of cellular damage by nicotine which leads to accumulation of lipids in the hepatic cells (as observed on the histological section) and hence increase in liver weight.

\section{Pituitary:}

The observed necrosis and degeneration of the cells especially in the anterior region of the pituitary gland may be due to the reported vasoconstrictive effect of nicotine (Milart, 1994). This may also explain the observed effects of nicotine on pituitary hormones. Nicotine has been reported to inhibit the release of $\mathrm{GH}$, an hormone of the anterior pituitary gland ((Morgan et al, 2004). Other studies have shown that subcutaneous injection of nicotine on the day of proestrous delay the usual surge of LH and also decrease the peak level when compared with the control (Blake et al, 1972).

Ovary and uterus:

Fibrosis, follicular degeneration and endometrial degeneration observed in the ovary and uterus following chronic nicotine administration in this study may explain the reason for early onset of menopause observed among smokers by Kaufman et al (1980). Other workers have reported an increase in number of regressing follicles in the ovary and reduction in the thickness of myometrium and endometrium in nicotine treated albino rats (Patil et al, 1999). Since steroids are needed for growth and development of female reproductive organs (Moordian, et al, (1987) the degeneration in the ovary and the uterus observed in this study could not be unconnected with the nicotine-induced inhibition of steroidogenesis, (Sanders et al 2002). Patra et al, (1979) has earlier reported that nicotine will either interfere with estrogen production or the ability of estrogen to regulate follicular development thus the delayed in ovulation following nicotine administration reported by Iranloye and Bolarinwa (2007).

\section{Brain and adrenal:}

According to Abel, (1983) following nicotine administration, three main areas achieve high concentration, the brain, pituitary and adrenal. Necrosis and weight reduction in the brain observed in this study confirms the vasoconstrictive effect of nicotine (Milart, 1994). Also the increase weight of the adrenal with nicotine treatment indicates the hyperactivity of the gland as nicotine causes the release of epinephrine which in-turn cause vasoconstriction.

Heart:

This work for the first time reports the effect of chronic nicotine treatment on the weight and histological section through the heart. The observed reduction in heart weight and presence of dead cells following 30 days nicotine treatment may be due to the release of epinephrine which causes vasoconstriction and hence reduced blood supply to the heart tissues. Thrombus seen on the histological section through the heart is consistent with the observed coronary thrombosis in smokers (Sidney et $a l, 1993$ ) while the calcified plaque observed with progressive nicotine treatment (60days) in this study is similar to the atherosclerosis reported in human smokers (Kjeidser, 1969).

\section{References}

Abel, E. L. (1983). In: Marihuana, Tobacco, Alcohol and Reproduction. pp. 55-11

Alada, A. R. A., (2001). Effect of cow's urine concoction on the flow and composition of bile in the rat. Mr. J. Iomed. Res. 4:47-50.

Bardy, A., Sepala, T., Lillsunde, P.; Kataja, J.M., Koskeld, P., Pikkarainen, J., Hillesmaa, V.K. (1993). Objectively measured tobacco exposure during pregnancy: Neonatal effects and relation to maternal smoking Br. J. Obstet Gynaecol. 100 (8): 721-726.

Benowitz, N. L., Florence, M.D., Kuyt, M.D. and Peyton Jacob 11 (1982a). Circadian Blood nicotine concentration, during cigarette smoking. Clin. Pharmacol. Ther 32(6): 758.

Benowitz, N.L. Florence, M.D., Kuyt, M.D. and Peyton Jacob III (1984). Influence of nicotine on $\mathrm{CV}$ and hormonal effects of cigarette smoking. Clin. Pharmacol. Ther. 36(1): 74-81.

Birnbaum, S. C., Kien, N., Martuca, R. W., Gielziechter, T. R., Witsch, H., Hendrick, A. G. and Last, J. A. (1994). Nicotine or epinephrine 
B. O. Iranloye and A. F. Bolarinwa

induced uteroplacental vasoconstriction and fetal growth in rat. Toxicol. 94: 69-80.

Blake, C A, Norman, R L, and Sawyer, C II (1972). Effect of nicotine on proestrus ovulations surge of LH in rat Endocrinol. 91: 1253- 1258.

Brodie, I. (1994). Tobbacco moguls say - cigarettes are not addictive. The tomes; 15 th April.

Economides, D. and Braithwaite, J. (1994). Smoking, Pregnancy and the fetus. J-R Soc-Health 114 (4): 198- 201.

Familusi, J. B. and Sinnette, C. H. (1977). Febrile convulsions in Ibadan children. Afr. J. Med. med. Sci. 2: 135-149.

Fergusson, D. M., Horwood, L. J., Shannon, F. T. and Taylor, B. (1981). Parental smoking and lower respiratory illness in the first three years of life. J. Epidemiol. Community Health. 35:180184.

George Howard, Lynne E. Wagenknecht, Gregory L. Burke, Ana Diez-Roux, Gregory W. Evans, Paul McGovern, F. Javier Nieto, Grethe S. (1998). Tell, Cigarette Smoking and Progression of Atherosclerosis JAMA. 279 (2): 119-124.

Halliwell B. (1993a): Free radicals and vascular diseases: how much do we know? Br. Med. J. 307.885.

Halliwell, B. (1993b). Cigarette smoking and health: a radical review. J. Roy Soc. Health. 91-96.

Hanrahan, J. P., Tagger T. B., Segal, M. R., Tosteson, T. D., Castile, R. G., Vanvunakis, H., Weiss, S. T. and Speizer, F. E. (1992). The effect of maternal smoking during pregnancy on early infant lung function. Am. Rev. Resp. Dis. 145:1129-1135.

Hughes, E. G. and Brennan B. G. (1996). Does cigarette smoking impair natural or assisted fecundity? Fertil Steril. 66:679-689.

Iranloye B. O. and Bolarinwa A. F. (2007). Effect of Nicotine administration on estrous cycle in female rats. Niger. J. Health and Biomed. Sci. 6: 21-25.

Kaufman, D.W., Slone, D, Rosenbegg, L., Miettinen, O.S., and Shapiro, S. (1980). Cigarette smoking and age at natural menopause. Am. J. Public Health; 70:420.

Martinez, F. D., Cline, M. and Burrows, B. (1992). Increased incidence of asthma in children of smoking mothers. Pediatrics. 89: 21-26.

Martin, D. W. Jr., (1983). Blood plasma and clothing. In: Harper's Review of Biochemistry. 19 ed. Pp. 559-572.

Milart, P., Kauffels-W. and Schneider, J. (1994). Vasoactive effects of nicotine in human umbilical arteries-Zentral-Gynakol 116(4):217-219.
Mooradian, A. D., Morley, J. E., and Korenman, S. G. (1987). Biological actions of androgen. Endocrinol. Rev. 8: 1-12.

Morgan, T. M., Crawford, L., Stoller, A., Toth, D., Yeo, K. T. and Baron, J. A. (2004). Acute effects of nicotine on serum glucose insulin growth hormone and cortisol in healthy smokers. Metabolism. 53(5): 578-582.

Oyebola, D.D.O and Adetuyibi, A. (1977). Toxicity of modified preparation of cow's urine concoction in mice. Trans R. Soc. Trop. Med. Hyg. 71:34950.

Patil, S., Patil, S., Bhaktaraj, B. and Patil, S. B. (1999). Effect of graded doses of nicotine on ovarian and uterine activities in albino rats. Indian J Exp Biol. 37(2):184-186.

Patra; P. B. B. Sanyal, S. and Biswas, N. M. (1979). Possible alpha-adrenergic involvement in nicotine induced alteration of spermatologenesis in rat. Andrologia 11(4): 273-278.

Perkins, K. A., Sexton, J. E., DiMarco, A. and Fonte, C. (1994). Acute effects of tobacco smoking on hunger and eating in male and female smokers. Appetite. 22(2):149-58.

Rosevear, S. K., Holt, D. W., Lee, T. D., Ford, W. C., Wardl, P. G. and Hull, M. G. (1992). Smoking and decreased fertilization rates in vitro. Lancet 340:1409-1410.

Sanders, S. R., Cuneo, S. P., Turzillo, A. M. (2002). Effects of nicotine and cotinine on bovine theca interna and granulose cells. Reprod. Toxicol. 16(6):795-800.

Seller, M. J. and Bnait, K. S. (1995). Effect of tobacco smoke inhalation on the developing mouse embryo and fetus. Reprod. Toxicol. 9(5):449-459.

Sidney. S., Sternfeld, B., Gidding, S. S., Jacobs, D.R. Jr. Bud, D. E.; Obermam, A., Haskeu, V., Crow R. S. and Gardin, J. M. (1993). Cigarette smoking and sub maximal exercise test duration in biracial population of young adults: The CARDIA study Med. Sci sports. Exerc 25:911-916.

Walsh, R. A. (1994). Effects of maternal smoking on adverse pregnancy outcomes Examination of the criteria of causation. Hum. Biol. 66(6): 1059-92.

Weisberg E. (1985). Smoking and reproductive health. Clin. Reprod. Fertil. 3(3):175-86 Weitzman, M., Gortmaker, S.,Walker, D.K. Sobol; A. (1990): Maternal smoking and childhood asthma. Pediatrics. 85: 505-511.

Winders SE and Grunberg NE. (1990). Effects of nicotine on body weight, food consumption and body composition in male rats. Life Sci. 46: 15231530 . 